\title{
Comprehensive Medication Management and Medication Adherence for Chronic Conditions
}

\author{
Amanda Brummel, PharmD, BCACP, and Angeline M. Carlson, PhD
}

\section{ABSTRACT}

BACKGROUND: The beneficial clinical effects of medication adherence have been consistently reported across most chronic diseases. Medication nonadherence carries significant economic and clinical burden. Medication therapy management (MTM) services aim to optimize pharmacotherapy and improve medication adherence.

OBJECTIVE: To evaluate the impact of exposure to face-to-face comprehensive medication management (CMM) services on medication adherence across 4 classes of chronic disease medications: oral diabetes medications, statins, angiotensin-converting enzyme inhibitors (ACEIs) or angiotensin II receptor blockers (ARBs), and beta-blockers.

METHODS: Pharmacy claims of continuously enrolled employees of a large Midwest integrated health system were retrieved for the period 2007-2011. Retrospective analysis was used to compare medication adherence measured using proportion of days covered (PDC) in employees who received CMM with employees who did not (control group). The pharmacy MTM program used the Patient-Centered Primary Care Collaborative standard of care. The CMM group's index date was the date of the first CMM visit; the non-CMM group's index date was randomly chosen from all therapeutic class-specific prescription claims dates. For each therapeutic class, patients with at least 1 prescription fill in both the measurement period (365 days post-index) and the baseline period (365 days pre-index) were included. The primary outcome measure was the PDC.

RESULTS: The CMM group had consistently higher and statistically significant PDC levels across all the therapeutic classes in the measurement period $(P<0.05)$ when looking at the unadjusted comparison. In the multivariate models, CMM exposure was associated with higher PDC; the difference between groups was statistically significant in all therapeutic classes except for oral diabetes medications (oral diabetes medications: $0.0403,95 \%$ confidence limits $[C L]=-0.0050,0.0850$; statins: 0.0769 , 95\% CL=0.0480, 0.1050; ACEls/ARBs: $0.1083 ; 95 \% \mathrm{CL}=0.0710,0.1450$; and beta-blockers: $0.0484 ; 95 \% \mathrm{CL}=0.0060,0.0910$ ). Logistic regression showed that the CMM group had an increased probability of meeting the $80 \%$ PDC cut-point for statins $(3.36,95 \% \mathrm{CL}=0.048,0.105)$; ACEIs/ARBs $(3.57,95 \% \mathrm{CL}=2.35,5.42)$; and beta-blockers $(2.56,95 \% \mathrm{CL}=1.57,4.18)$.

CONCLUSIONS: Exposure to face-to-face CMM services resulted in improvement of medication adherence. CMM is a powerful practice model that should be encouraged by insurers and health plan administrators to increase rates of medication adherence.

J Manag Care Spec Pharm. 2016;22(1):56-62

Copyright $\odot 2016$, Academy of Managed Care Pharmacy. All rights reserved.

\section{What is already known about this subject}

Medication nonadherence is prevalent among U.S. patients in general, with higher rates reported in the elderly population. Comprehensive medication management (CMM) is a service that aims to optimize clinical outcomes by managing drug therapies for patients with chronic diseases. These outcomes include improving patients' understanding of their diseases/medications, reducing drug-adverse events, meeting patient-defined clinical goals, and improving medication adherence.

Medication adherence has been studied in a variety of practice settings and with different models of practice. There are inconsistences in beneficial outcomes reported among these studies that may in part be due to differences in methodology, program implementation, and patient populations.

\section{What this study adds}

This study evaluates the impact of exposure to face-to-face CMM services on medication adherence across 4 classes of chronic disease medications: oral diabetes medications, statins, angiotensinconverting enzyme inhibitors (ACEIs) or angiotensin II receptor blockers (ARBs), and beta-blockers.

In the therapeutic classes examined, the CMM group had consistently higher, statistically significant proportion of days covered (PDC) levels across all the therapeutic classes $(P<0.050)$ when we looked at the unadjusted comparison of PDC at baseline and the measurement period.

Exposure to face-to-face CMM services resulted in improvement of medication adherence measured by PDC across multiple chronic disease medication classes.

T he beneficial clinical effects of medication adherence have been consistently reported across most chronic diseases. ${ }^{1-5}$ Unfortunately, medication nonadherence is prevalent among U.S. patients in general, with higher rates reported in the elderly population. ${ }^{6}$ Nonadherence carries with it a substantial clinical and economic burden. One report has estimated the cost of nonadherence in the United States at $\$ 290$ billion per year. ${ }^{7}$ Another study reported that nonadherence for patients with diabetes, hypertension, and dyslipidemia totaled a U.S. national cost of $\$ 105.8$ billion in 2010 , or $\$ 453$ per adult. ${ }^{8}$ 
TABLE 1 Baseline Characteristics

\begin{tabular}{|c|c|c|c|c|c|c|c|c|c|c|c|c|}
\hline \multirow[b]{2}{*}{ Characteristic } & \multicolumn{3}{|c|}{ Oral Diabetes Medications } & \multicolumn{3}{|c|}{ Statins } & \multicolumn{3}{|c|}{ ACEIs/ARBs } & \multicolumn{3}{|c|}{ Beta-blockers } \\
\hline & $\begin{array}{c}\text { CMM } \\
\mathrm{N}=159\end{array}$ & $\begin{array}{c}\text { Non-CMM } \\
\mathrm{N}=318\end{array}$ & $P$ Value & $\begin{array}{c}\text { CMM } \\
\mathrm{N}=242\end{array}$ & $\begin{array}{c}\text { Non-CMM } \\
\mathrm{N}=1,314\end{array}$ & $P$ Value & $\begin{array}{c}\text { CMM } \\
\mathrm{N}=160\end{array}$ & $\begin{array}{c}\text { Non-CMM } \\
\mathrm{N}=904\end{array}$ & $P$ Value & $\begin{array}{c}\mathrm{CMM} \\
\mathrm{N}=123\end{array}$ & $\begin{array}{c}\text { Non-CMM } \\
\mathrm{N}=820\end{array}$ & $P$ Value \\
\hline Age & 55.88 & 50.94 & $<0.001$ & 56.94 & 54.75 & $<0.001$ & 57.08 & 54.45 & $<0.001$ & 57.98 & 53.28 & $<0.001$ \\
\hline Sex (females) & $51.57 \%$ & $57.86 \%$ & 0.190 & $54.96 \%$ & $47.64 \%$ & 0.040 & $54.38 \%$ & $49.89 \%$ & 0.300 & $52.03 \%$ & $58.90 \%$ & 0.150 \\
\hline Sum of copays & $\$ 685$ & $\$ 588$ & $<0.001$ & $\$ 719$ & $\$ 505$ & $<0.001$ & $\$ 682$ & $\$ 532$ & $<0.001$ & $\$ 757$ & $\$ 524$ & $<0.001$ \\
\hline Sum of prescribers & 3.79 & 4.17 & 0.130 & 4.10 & 3.55 & $<0.010$ & 4.53 & 3.91 & $<0.010$ & 5.02 & 4.18 & $<0.010$ \\
\hline Sum of pharmacies & 2.57 & 2.45 & 0.380 & 2.68 & 2.30 & $<0.001$ & 2.69 & 2.39 & 0.010 & 2.76 & 2.32 & $<0.001$ \\
\hline Drug count & 11.64 & 10.23 & 0.020 & 12.12 & 7.07 & $<0.001$ & 12.17 & 7.89 & $<0.001$ & 13.77 & 8.31 & $<0.001$ \\
\hline PDC at baseline & $74.69 \%$ & $69.31 \%$ & 0.080 & $75.03 \%$ & $72.02 \%$ & 0.130 & $75.63 \%$ & $73.72 \%$ & 0.440 & $78.42 \%$ & $73.13 \%$ & 0.060 \\
\hline Mail order pharmacy & $44.65 \%$ & $30.50 \%$ & $<0.010$ & $52.07 \%$ & $40.49 \%$ & $<0.001$ & $52.50 \%$ & $35.62 \%$ & $<0.001$ & $43.90 \%$ & $32.56 \%$ & 0.010 \\
\hline \multicolumn{13}{|l|}{ Baseline comorbidities } \\
\hline Cardiac disorders & $49.69 \%$ & $44.34 \%$ & 0.260 & $50.00 \%$ & $42.24 \%$ & 0.030 & $64.38 \%$ & $56.31 \%$ & 0.060 & $98.37 \%$ & $98.66 \%$ & 0.800 \\
\hline Gastric disorders & $24.53 \%$ & $21.38 \%$ & 0.430 & $34.71 \%$ & $24.96 \%$ & $<0.010$ & $33.75 \%$ & $21.79 \%$ & $<0.001$ & $43.09 \%$ & $24.88 \%$ & $<0.0001$ \\
\hline Gout & $7.55 \%$ & $7.55 \%$ & 1.000 & $16.53 \%$ & $9.82 \%$ & $<0.010$ & $13.13 \%$ & $11.73 \%$ & 0.610 & $19.51 \%$ & $10.12 \%$ & $<0.010$ \\
\hline Lipid disorders & $79.25 \%$ & $62.89 \%$ & $<0.001$ & $99.59 \%$ & $100.00 \%$ & 0.020 & $75.63 \%$ & $49.56 \%$ & $<0.001$ & $70.73 \%$ & $42.44 \%$ & $<0.0001$ \\
\hline Hypertension & $25.79 \%$ & $26.73 \%$ & 0.820 & $26.45 \%$ & $21.84 \%$ & 0.120 & $36.25 \%$ & $34.40 \%$ & 0.650 & $42.28 \%$ & $37.20 \%$ & 0.270 \\
\hline $\begin{array}{l}\text { Inflammatory bowel } \\
\text { disorders }\end{array}$ & $5.03 \%$ & $4.40 \%$ & 0.760 & $5.79 \%$ & $4.41 \%$ & 0.350 & $5.00 \%$ & $4.31 \%$ & 0.700 & $6.50 \%$ & $4.51 \%$ & 0.330 \\
\hline Malignancy & $6.29 \%$ & $8.81 \%$ & 0.330 & $9.92 \%$ & $5.63 \%$ & 0.010 & $10.00 \%$ & $6.97 \%$ & 0.180 & $12.20 \%$ & $8.41 \%$ & 0.170 \\
\hline Psychiatric disorders & $42.14 \%$ & $38.99 \%$ & 0.500 & $53.31 \%$ & $37.90 \%$ & $<0.001$ & $43.13 \%$ & $38.83 \%$ & 0.300 & $54.47 \%$ & $43.29 \%$ & 0.020 \\
\hline Thyroid disease & $13.84 \%$ & $14.78 \%$ & 0.780 & $16.94 \%$ & $12.63 \%$ & 0.070 & $15.00 \%$ & $10.07 \%$ & 0.060 & $19.51 \%$ & $11.46 \%$ & 0.010 \\
\hline Transplant & $0.00 \%$ & $1.26 \%$ & 0.300 & $1.65 \%$ & $1.67 \%$ & 0.980 & $2.50 \%$ & $1.11 \%$ & 0.150 & $4.88 \%$ & $1.59 \%$ & 0.020 \\
\hline Glaucoma & $6.92 \%$ & $5.97 \%$ & 0.690 & $10.33 \%$ & $5.48 \%$ & $<0.010$ & $8.13 \%$ & $4.87 \%$ & 0.090 & $14.63 \%$ & $2.68 \%$ & $<0.0001$ \\
\hline$\overline{\mathrm{HIV}}$ & $4.40 \%$ & $6.60 \%$ & 0.330 & $5.79 \%$ & $6.77 \%$ & 0.570 & $4.38 \%$ & $6.97 \%$ & 0.220 & $6.50 \%$ & $6.59 \%$ & 0.970 \\
\hline Respiratory disease & $38.99 \%$ & $39.94 \%$ & 0.840 & $45.04 \%$ & $35.77 \%$ & $<0.010$ & $46.88 \%$ & $39.05 \%$ & 0.060 & $52.85 \%$ & $40.00 \%$ & $<0.010$ \\
\hline Renal disorders & $0.63 \%$ & $0.63 \%$ & 1.000 & $0.83 \%$ & $0.30 \%$ & 0.240 & $1.25 \%$ & $0.33 \%$ & 0.160 & $2.44 \%$ & $0.73 \%$ & 0.100 \\
\hline Cystic liver & $0.00 \%$ & $0.63 \%$ & 0.310 & $0.83 \%$ & $0.53 \%$ & 0.630 & $0.63 \%$ & $0.33 \%$ & 0.480 & $0.81 \%$ & $0.24 \%$ & 0.340 \\
\hline
\end{tabular}

Medication therapy management (MTM) is a pharmacist-led and delivered service that aims to optimize clinical outcomes by managing drug therapies for patients with chronic diseases. MTM was officially recognized in the Medicare Prescription Drug Modernization Act as a service that targets patients with chronic diseases who are taking multiple medications. The goals of pharmacists' interventions are improving patients' understanding of their diseases/medications, reducing drugadverse events, meeting patient-defined clinical goals, and improving medication adherence. ${ }^{9}$

In 2007, the Centers for Medicare \& Medicaid Services (CMS) developed the Medicare star rating system. Star ratings are a part of efforts that CMS has implemented to define, measure, and reward quality health care delivered via the health plans. There are 3 star ratings that are directly focused on medication adherence. These measures target oral diabetes medications, antihypertensive agents (renin-angiotensin system antagonists), and statin medications for cholesterol. The metric that is used to measure adherence is proportion of days covered (PDC), which defines high adherence to be $80 \%$ or greater of days covered. ${ }^{3}$
A number of studies have assessed the clinical and economic outcomes of MTM programs. Examples include programs evaluated in Minnesota, ${ }^{10}$ North Carolina, ${ }^{11,12}$ Iowa, ${ }^{13}$ and Connecticut. ${ }^{14}$ Fewer studies have assessed behavioral outcomes like medication adherence, with mixed, although generally encouraging, results. For instance, Hirsch et al. (2011) found that human immunodeficiency virus/acquired immunodeficiency syndrome patients who used community-offered MTM services were more likely to adhere to their antiretroviral medication..$^{15}$ Zillich et al. (2012) reported an overall increase in the medication adherence in a cohort of Medicaid patients receiving specialized medication packaging and telephonic MTM services when these patients were compared with those receiving usual care. ${ }^{16}$

The medications that were packaged in this study included all prescription medications, over-the-counter medications, and vitamins. Medication compliance was computed using the medication possession ratio (MPR). A recent study by Pringle et al. (2014) found that community pharmacists' interventions improved adherence in 5 medication classes compared with a control group..$^{17}$ Those medication classes include oral diabetes medications, statins, angiotensin-converting enzyme inhibitors 


\begin{tabular}{|c|c|c|c|c|c|c|c|c|c|c|c|c|}
\hline & \multicolumn{3}{|c|}{ Oral Diabetes Medications } & \multicolumn{3}{|c|}{ Statins } & \multicolumn{3}{|c|}{ ACEIs/ARBs } & \multicolumn{3}{|c|}{ Beta-blockers } \\
\hline & $\begin{array}{c}\text { CMM } \\
\mathrm{N}=159 \\
(\%)\end{array}$ & $\begin{array}{c}\text { Non- } \\
\text { CMM } \\
\mathrm{N}=318 \\
(\%)\end{array}$ & $P$ Value & $\begin{array}{c}\text { CMM } \\
\mathrm{N}=242 \\
(\%)\end{array}$ & $\begin{array}{c}\text { Non- } \\
\text { CMM } \\
\mathrm{N}=1,314 \\
(\%)\end{array}$ & $P$ Value & $\begin{array}{c}\text { CMM } \\
\mathrm{N}=160 \\
(\%)\end{array}$ & $\begin{array}{c}\text { Non- } \\
\text { CMM } \\
\mathrm{N}=904 \\
(\%)\end{array}$ & $P$ Value & $\begin{array}{c}\text { CMM } \\
\mathrm{N}=123 \\
(\%)\end{array}$ & $\begin{array}{c}\text { Non- } \\
\text { CMM } \\
\text { N=820 } \\
(\%)\end{array}$ & $P$ Value \\
\hline PDC at baseline & 74.69 & 69.31 & 0.080 & 75.03 & 72.02 & 0.130 & 75.63 & 73.72 & 0.440 & 78.42 & 73.13 & 0.060 \\
\hline PDC at measurement period & 81.84 & 72.63 & $<0.001$ & 73.45 & 65.06 & $<0.001$ & 77.48 & 66.36 & $<0.001$ & 73.57 & 65.03 & $<0.010$ \\
\hline
\end{tabular}

(ACEIs)/angiotensin II receptor blockers (ARBs), beta-blockers, and calcium channel blockers. PDC80 was used to measure the adherence result. In contrast, Moczygemba et al. (2011) found that telephone-based MTM services did not improve adherence in a sample of Medicare Part D patients in 6 months of follow-up. ${ }^{18}$ MPR was used to measure the adherence rates in the Medicare Part D medications.

MTM is a term that may carry multiple meanings when discussing it as a practice, however. As stated by Harris et al. (2014) in a recent American College of Clinical Pharmacy white paper, "Although studies assessing the effects of clinical pharmacists on health care outcomes have shown positive results in varied practice settings, these studies used different or unspecified processes of care." ${ }^{\prime 19}$ Some practices are engaged in assessing all of a patient's needs, while others focus on a sole condition or issue. Different practice models or care processes could explain the differences in MTM outcomes reported in literature.

This study, unlike the previous studies, evaluates the impact of exposure to face-to-face comprehensive medication management $(\mathrm{CMM})$ services on medication adherence across 4 classes of chronic disease medications: oral diabetes medications, statins, ACEIs or ARBs, and beta-blockers. CMM, as defined by the Patient-Centered Primary Care Collaborative (PCPCC), is the standard of care that ensures each patient's medications are individually assessed to determine that each medication is appropriate for the patient, effective for the medical condition, safe given the comorbidities and other medications being taken, and able to be taken by the patient as intended. It includes an individualized care plan that achieves the intended goals of therapy with appropriate follow-up to determine actual patient outcomes. ${ }^{20}$

\section{Methods}

The pharmacy MTM program uses a standardized patient care process within the integrated health system that follows the pharmaceutical care model, ${ }^{21}$ which also aligns with the PCPCC standard of care. Each CMM encounter follows a systematic review process designed to identify and resolve drug therapy problems and promote optimal patient outcomes. ${ }^{22}$ CMM pharmacists' responsibilities include (a) focus on the "whole" patient (the pharmacist assesses all of the patient's diseases and medications); (b) identification of a patient's drug-related needs and the commitment to meet these needs; (c) assurance that all of a patient's drug therapy is appropriately indicated and is the most effective and the safest therapy, and that the patient is compliant, through the identification, resolution, and prevention of drug-related problems; (d) achievement of therapy outcomes and assurance of documentation of those outcomes; and (e) work in collaboration with all members of a patient's care team.

Pharmacy claims data were used for the years 2007-2011 from employees of a large Midwest integrated health system. The claims data included patient's age, sex, dispensed medications, dates of fill, type of pharmacies used for filling the prescription (community retail, mail order), and prescribing physician information. An electronic MTM software (Assurance, Medication Management Systems Inc., Golden Valley, MN) was used to identify employees who received CMM services and the number and dates of all CMM visits during the same observation period. Employees who did not receive CMM services were included in a control (non-CMM) group. All employees were eligible for CMM services. Employees with chronic conditions were emailed a letter to bring awareness to the CMM program. Employees determined whether to participate in CMM services.

To determine baseline and measurement periods for comparison, we established an index date for each of the 2 study groups. For CMM patients, the index date was defined as the date of the first recorded CMM visit. For non-CMM patients, the index date was selected randomly from all dates of prescription fills for a specific drug class cohort (i.e., a non-CMM employee could be included in multiple drug class cohorts, each having a different index date). The baseline period was then defined as the 365 days prior to the index date, and the measurement period was defined as the 365 days following the index date.

Prescriptions in the 4 studied drug classes were defined based on generic product identifier codes: oral diabetes medications $(2720,2725,2766,2799)$; statins (394000, 394099 , 399940); ACEIs/ARBs (3610, 3615); and beta-blockers (3310, $3320,3330)$. These classes were selected to follow the CMS 
TABLE 3 Linear Model Results (Significant Covariates Only)

\begin{tabular}{|c|c|c|c|c|c|c|c|c|c|c|c|c|}
\hline & \multicolumn{3}{|c|}{ Oral Diabetes Medications } & \multicolumn{3}{|c|}{ Statins } & \multicolumn{3}{|c|}{ ACEIs/ARBs } & \multicolumn{3}{|c|}{ Beta-blockers } \\
\hline & & $95 \% \mathrm{CL}$ & $P$ Value & & $95 \% \mathrm{CL}$ & $P$ Value & & $95 \% \mathrm{CL}$ & $P$ Value & & $95 \% \mathrm{CL}$ & $P$ Value \\
\hline Age & 0.0031 & $\begin{array}{c}0.0050 \\
0.0010\end{array}$ & $<0.010$ & 0.0014 & $\begin{array}{l}0.0001 \\
0.0030\end{array}$ & 0.035 & 0.0018 & $\begin{array}{c}0.0003 \\
0.0030\end{array}$ & 0.0220 & 0.0025 & $\begin{array}{l}0.0010 \\
0.0040\end{array}$ & 0.001 \\
\hline $\mathrm{CMM}$ & 0.0403 & $\begin{array}{c}-0.0050 \\
0.0850\end{array}$ & 0.080 & 0.0769 & $\begin{array}{c}0.0480 \\
0.1050\end{array}$ & $<0.010$ & 0.1083 & $\begin{array}{l}0.0710 \\
0.1450\end{array}$ & $<0.0001$ & 0.0484 & $\begin{array}{c}0.0060 \\
0.0910\end{array}$ & 0.026 \\
\hline $\begin{array}{l}\text { PDC at } \\
\text { baseline }\end{array}$ & 0.4218 & $\begin{array}{l}0.3540 \\
0.4890 \\
\end{array}$ & $<0.010$ & 0.3623 & $\begin{array}{l}0.3250 \\
0.3980 \\
\end{array}$ & $<0.010$ & 0.2775 & $\begin{array}{l}0.2320 \\
0.3220\end{array}$ & $<0.0001$ & 0.3635 & $\begin{array}{l}0.3150 \\
0.4120\end{array}$ & $<0.010$ \\
\hline $\begin{array}{l}\text { Sum of } \\
\text { copays }\end{array}$ & 0.0001 & $\begin{array}{l}0.0001 \\
0.0001\end{array}$ & $<0.010$ & 0.0001 & $\begin{array}{l}0.0001 \\
0.0001\end{array}$ & $<0.010$ & 0.0001 & $\begin{array}{l}0.00001 \\
0.00010\end{array}$ & $<0.0001$ & 0.0001 & $\begin{array}{l}0.00001 \\
0.00010\end{array}$ & $<0.010$ \\
\hline $\begin{array}{l}\text { Drug } \\
\text { count }\end{array}$ & - & - & - & - & - & - & -0.0047 & $\begin{array}{c}-0.0080 \\
-0.0010 \\
\end{array}$ & 0.0078 & - & - & - \\
\hline $\begin{array}{l}\text { Sum of } \\
\text { prescribers }\end{array}$ & - & - & - & 0.0058 & $\begin{array}{c}0.0003 \\
0.0114\end{array}$ & 0.040 & - & - & - & - & - & - \\
\hline $\begin{array}{l}\text { Sum of } \\
\text { pharmacies }\end{array}$ & - & - & - & - & - & - & - & - & - & - & - & - \\
\hline $\begin{array}{l}\text { Psychiatric } \\
\text { disorders }\end{array}$ & - & - & - & -0.0237 & $\begin{array}{l}-0.0450 \\
-0.0020 \\
\end{array}$ & 0.036 & - & - & - & - & - & - \\
\hline $\begin{array}{l}\text { Mail order } \\
\text { pharmacy }\end{array}$ & - & - & - & -0.0356 & $\begin{array}{l}-0.0580 \\
-0.0130\end{array}$ & $<0.010$ & - & - & - & - & - & - \\
\hline
\end{tabular}

ACEI = angiotensin-converting enzyme inhibitors; $A R B=$ angiotensin II receptor blocker; $C L=$ confidence limit; CMM = comprehensive medication management; $P D C=$ proportion of days covered.

star ratings when applicable. Employees who had at least 1 prescription fill within the specific therapeutic class in both the measurement period and the baseline period were included in the final study sample. This criterion ensured that patients were continually prescribed a drug from the therapeutic class of interest.

The primary outcome measure was the PDC, ${ }^{2,23}$ defined as the ratio of the number of days covered by prescription claims for the same medication or another in its therapeutic category using the days supply reported on the individual claims to the total number of days in the defined measurement period. ${ }^{24,25}$ Overlapping supply days were credited by moving the fill date forward to the day after the end of supply of the previous fill. To account for the fact that for CMM patients, the index date could occur on a day in which no class-specific drug was filled, a period of 90 days prior to the index date was used to determine whether the patient had a drug on hand in the days between the index date and the first fill after the index date.

Potential confounders that could affect the relationship between exposure to CMM services included age, sex, adherence in the year prior to the index date, the number of unique prescribing physicians as a measure of poly-medicine, use of mail order pharmacy, use of antidepressant drugs, and the sum of out-of-pocket expenditures (copays and deductibles) in the measurement period. Selected comorbidities were identified in the baseline period, based on prescription use. ${ }^{26}$ In addition, the number of unique medications not from the same specific therapeutic class $^{27}$ and the year of the index date were also included as control variables for the statistical analysis.
T-tests and chi-squared tests were used to compare the CMM group with the non-CMM group for the continuous and binary variables, respectively. Multivariate modeling was used where PDC was the outcome of interest and receiving CMM services was the exposure of interest. Ordinary least squares regression was used to model PDC as a continuous variable, with values ranging between 0 and 1 . Logistic regression was used to model PDC as a binary variable (adherent/nonadherent). The cut-point definition for PDC as a binary variable was set at $80 \%$, a commonly reported indicator of optimum adherence, ${ }^{1,28}$ and consistent with the benchmark that was developed by the Pharmacy Quality Alliance (PQA) and adopted by CMS star ratings. Statistical significance was determined at $P<0.050$. Statistical analyses were performed using SAS software package 9.2 (SAS Institute, Cary, NC).

\section{Results}

A summary of the baseline characteristics of the 4 study cohorts is presented in Table 1. The largest therapeutic class group was employees using statins (1,556 statin users [242 CMM, 1,314 non-CMM]). The CMM group had a consistently higher mean age, a higher average number of medications, and a greater proportion using mail order pharmacy across the 4 therapeutic classes $(P<0.050)$. The CMM group also had consistently higher total copay amounts, and the difference was statistically significant in all 4 therapeutic classes. There were no significant differences in PDC between the CMM and non-CMM groups at baseline for any therapeutic classes. 
TABLE 4 Logistic Regression Results (Significant Confounders Only)

\begin{tabular}{|c|c|c|c|c|c|c|c|c|c|c|c|c|}
\hline & \multicolumn{3}{|c|}{ Oral Diabetes Medications } & \multicolumn{3}{|c|}{ Statins } & \multicolumn{3}{|c|}{ ACEIs/ARBs } & \multicolumn{3}{|c|}{ Beta-blockers } \\
\hline & $\begin{array}{l}\text { Odds } \\
\text { Ratio }\end{array}$ & $95 \% \mathrm{CL}$ & $P$ Value & $\begin{array}{l}\text { Odds } \\
\text { Ratio }\end{array}$ & $95 \% \mathrm{CL}$ & $P$ Value & $\begin{array}{l}\text { Odds } \\
\text { Ratio }\end{array}$ & $95 \%$ CL & $P$ Value & $\begin{array}{l}\text { Odds } \\
\text { Ratio }\end{array}$ & $95 \%$ CL & $P$ Value \\
\hline$\overline{\text { Age }}$ & 1.04 & $\begin{array}{l}1.01, \\
1.06\end{array}$ & 0.0054 & 1.020 & $\begin{array}{l}1.000 \\
1.030\end{array}$ & 0.0221 & - & - & - & 1.02 & $\begin{array}{l}1.00 \\
1.04\end{array}$ & 0.0129 \\
\hline$\overline{\mathrm{CMM}}$ & 1.54 & $\begin{array}{l}0.91 \\
2.62\end{array}$ & 0.1100 & 3.360 & $\begin{array}{l}0.048 \\
0.105\end{array}$ & $<0.0001$ & 3.57 & $\begin{array}{l}2.35 \\
5.42 \\
\end{array}$ & $<0.0001$ & 2.56 & $\begin{array}{l}1.57 \\
4.18 \\
\end{array}$ & 0.0002 \\
\hline $\begin{array}{l}\text { Adherent at } \\
\text { baseline }\end{array}$ & 6.52 & $\begin{array}{l}4.02, \\
10.6\end{array}$ & $<0.0001$ & 4.580 & $\begin{array}{l}3.500 \\
5.990\end{array}$ & $<0.0001$ & 3.92 & $\begin{array}{l}2.85 \\
5.39\end{array}$ & $<0.0001$ & 19.06 & $\begin{array}{l}9.84 \\
36.92\end{array}$ & $<0.0001$ \\
\hline $\begin{array}{l}\text { Sum of } \\
\text { copays }\end{array}$ & 2.34 & $\begin{array}{l}1.25 \\
4.40\end{array}$ & 0.0079 & 1.450 & $\begin{array}{l}1.060 \\
1.970\end{array}$ & 0.0198 & 1.98 & $\begin{array}{l}1.36 \\
2.86\end{array}$ & 0.0003 & 2.44 & $\begin{array}{l}1.62 \\
3.67\end{array}$ & $<0.0001$ \\
\hline Drug count & - & - & - & - & - & - & - & - & - & - & - & - \\
\hline $\begin{array}{l}\text { Number of } \\
\text { prescribers }\end{array}$ & - & - & - & - & - & - & 1.11 & $\begin{array}{l}1.02 \\
1.20 \\
\end{array}$ & 0.0145 & - & - & - \\
\hline $\begin{array}{l}\text { Number of } \\
\text { pharmacies }\end{array}$ & - & - & - & - & - & - & - & - & - & - & - & - \\
\hline $\begin{array}{l}\text { Psychiatric } \\
\text { disorders }\end{array}$ & - & - & - & - & - & - & - & - & - & - & - & - \\
\hline $\begin{array}{l}\text { Mail order } \\
\text { pharmacy }\end{array}$ & - & - & - & 0.165 & $\begin{array}{l}0.120 \\
0.220\end{array}$ & $<0.0001$ & 0.20 & $\begin{array}{l}0.14 \\
0.29\end{array}$ & $<0.0001$ & 0.13 & $\begin{array}{l}0.09 \\
0.20\end{array}$ & $<0.0001$ \\
\hline
\end{tabular}

$A C E I=$ angiotensin-converting enzyme inhibitor; $A R B=$ angiotensin II receptor blocker; $C L=$ confidence limit; $C M M=$ comprehensive medication management.

Table 2 provides the unadjusted comparison of PDC at baseline and the measurement period for each therapeutic class. The CMM group had consistently higher, statistically significant PDC levels across all the therapeutic classes in the measurement period $(P<0.050)$. The highest absolute difference between the CMM and non-CMM groups was observed in the ACEIs/ARBs cohort (77.48\% vs. $66.36 \%, P<0.001)$; the lowest absolute difference was found with the statin cohort (73.45\% vs. $65.06 \%, P<0.001)$.

Multivariate linear models revealed that enrollment in CMM services was significantly associated with improved adherence rates as measured by increases in PDC in 3 of the therapeutic classes studied: statins, ACEIs/ARBs, and beta-blockers (Table 3). Having a higher PDC in the baseline period was, as hypothesized, also associated with improved adherence in the measurement period. None of the remaining variables were found to be consistently significant.

Results using the 80\% PDC cut-point as an indicator of optimal adherence within a logistic regression framework were generally consistent with linear model results. With the exception of the oral diabetes medications cohort, the CMM group was associated with a significantly higher likelihood of having adherence of $80 \%$. Also as anticipated, adherence at baseline was associated with higher odds of adherence in the measurement period (Table 4).

\section{Discussion}

Medication adherence is a complex problem that involves a multitude of social, psychological, and clinical factors. ${ }^{29}$ Medication nonadherence is expected to continue as a concern in the U.S. health care system because of the evidence of its high prevalence and the heavy clinical and economic costs associated with it. ${ }^{30}$ In an effort to help resolve this problem, CMS recognized MTM programs as patient-centered pharmacy services with multiple related goals, one of which is improving medication adherence. This was also recognized in the inclusion of 3 adherence measures in the star ratings program.

This research conducted a retrospective analysis of employees' pharmacy claims in a large integrated health care system to assess prescription drug adherence using the PQA-endorsed PDC measure across 4 commonly used chronic medication categories. The therapeutic classes studied represent medications used for diabetes, cardiovascular disorders (hypertension and congestive heart failure), and hypercholesterolemic disorders. Three of these classes are in the star ratings program-oral diabetes medications, statin medications for cholesterol, and antihypertensive agents (renin-angiotensin system antagonists). Across all the therapeutic classes, adherence rates for CMM patients improved in the 365 days that followed the initial exposure to CMM as compared with control patients. When controlling for potential confounders in multivariate analyses, we found that the oral diabetes medications cohort was the only therapeutic class in which higher adherence rates, while improved in CMM patients, was not significantly higher than for the control patients. Consistent with the linear models that treated PDC as a continuous measure, logistic regression showed similar beneficial effects of CMM on the odds of meeting the generally recognized adherence goal of $80 \%$ reported for PDC. 
This article reflects the approach of CMM. Comparing these findings with the previous research is difficult because of inconsistencies in the measured outcomes; differences in recruitment and patient identification; differences in the practice models/interventions; and finally, differences in patient populations. However, as previous research shows, CMM is associated with improvements in medication adherence.

Medication adherence is viewed as an essential component of effective chronic disease treatment. Research findings have been inconsistent, however, in identifying interventions that will lead to improvement in patients' adherence to prescribed therapy. ${ }^{31}$ Studies that have reported improvements in both adherence and clinical outcomes have assessed complex interventions with multiple components that include ongoing support from pharmacists and other health professionals. Increasing patients' adherence should add to the economic value offered through CMM services. Research has demonstrated that improved adherence among patients with diabetes, hypertension, hypercholesterolemia, and congestive heart failure has reduced hospitalization rates with an overall reduction in total health care costs. ${ }^{32}$ Together with reaping the expected economic benefits of preventing and reducing adverse drug events by correcting drug therapy problems, ${ }^{9,33-35}$ optimizing medication adherence via CMM also can curb health care costs for chronic disease patients.

\section{Limitations}

Because of the nonrandomized nature of the study, there is a chance for residual confounding by unmeasured variables. For instance, unmeasured patients' characteristics like health beliefs and motivation levels that possibly made them more likely to opt in for CMM services and be more responsive to the CMM pharmacists' recommendations with regard to medication adherence were not measured.

While we did not observe CMM visits to assess fidelity to our protocols, we know that all pharmacists were trained in CMM. Quality assurance audits and peer review do occur on a quarterly basis.

Patients included in this study were employees or beneficiaries of a single Minnesota-based employer within the health care industry. These results may not be generalizable to employees of other sectors of the population.

The primary outcome measure, PDC, was calculated using a secondary data source, pharmacy claims data. This data source records the acquisition of the medication and the estimated days supply of the quantity obtained; as such, it does not measure patient-taking behaviors.

The focus of this study was to measure adherence. Future research would include both the medication adherence analysis as well as the economic analysis, integrating medical claims to outline the impact on provider visits, hospitalizations, and emergency room use.

\section{Conclusions}

Exposure to face-to-face CMM services resulted in improvement of medication adherence measured by PDC across multiple chronic disease medication classes. CMM is a powerful practice model that should be encouraged and covered by insurers and health plan administrators to increase rates of medication adherence.

\section{Authors}

AMANDA BRUMMEL, PharmD, BCACP, is Director, Clinical Ambulatory Pharmacy Services, Medication Therapy Management, Fairview Pharmacy Services, Minneapolis, Minnesota, and ANGELINE M. CARLSON, PhD, is Director of Research, Data Intelligence Consultants, Eden Prairie, Minnesota.

AUTHOR CORRESPONDENCE: Amanda Brummel, PharmD, $B C A C P$, Medication Therapy Management, Fairview Pharmacy Services, 711 Kasota Ave., SE, Minneapolis, MN 55414.

Tel.: 612.672.5585; Fax: 612.672.7320; E-mail: arhode1@fairview.org.

\section{DISCLOSURES}

No outside funding supported this research. The authors declare no conflicts of interest.

Study concept and design were primarily contributed by Carlson, along with Brummel. Brummel took the lead in data collection, with assistance from Carlson, with data interpretation performed by Carlson and Brummel. Both authors contributed equally to writing the manuscript, which was revised primarily by Brummel, along with Carlson.

\section{ACKNOWLEDGMENTS}

The authors would like to acknowledge Ahmed Soliman, PhD, for his contributions to the concept/design, data collection, and interpretation of this manuscript. They would also like to acknowledge Amy Herbranson, PharmD, for her help with revision of the manuscript.

\section{REFERENCES}

1. Benner JS, Glynn RJ, Mogun H, Neumann PJ, Weinstein MC, Avorn J. Long-term persistence in use of statin therapy in elderly patients. JAMA. 2002;288(4):455-61. Available at: http://jama.jamanetwork.com/article. aspx?articleid=195142. Accessed November 3, 2015.

2. Benner JS, Pollack MF, Smith TW, Bullano MF, Willey VJ, Williams SA. Association between short-term effectiveness of statins and long-term adherence to lipid-lowering therapy. Am J Health Syst Pharm. 2005;62(14):1468-75.

3. Kim N, Agostini JV, Justice AC. Refill adherence to oral hypoglycemic agents and glycemic control in veterans. Ann Pharmacother. 2010;44(5):800-08.

4. Rhee MK, Slocum W, Ziemer DC, et al. Patient adherence improves glycemic control. Diabetes Educ. 2005;31(2):240-50.

5. Krousel-Wood M, Thomas S, Muntner P, Morisky D. Medication adherence: a key factor in achieving blood pressure control and good clinical outcomes in hypertensive patients. Curr Opin Cardiol. 2004;19(4):357-62.

6. Osterberg L, Blaschke T. Adherence to medication. N Engl J Med. 2005;353(5):487-97. 
7. New England Healthcare Institute. Thinking outside the pillbox: a system-wide approach to improving patient medication adherence for chronic disease. A NEHI research brief. August 2009. Available at: http://www. nehi.net/writable/publication_files/file/pa_issue_brief_final.pdf. Accessed November 3, 2015

8. Nasseh K, Glave Frazee S, Visaria J, Vlahiotis A, Tian Y. Cost of medication nonadherence associated with diabetes, hypertension, and dyslipidemia. Am J Pharm Benefits. 2012;4(2):e41-47. Available at: http://www. ajmc.com/publications/ajpb/2012/AJPB_MarApr2012/Cost-of-MedicationNonadherence-Associated-With-Diabetes-Hypertension-and-Dyslipidemia. Accessed November 3, 2015

9. Medicare prescription drug, improvement, and modernization act of 2003. Pub. L. No. 108-173, 117 Stat 2066 (December 8, 2003). Available at: http://www.gpo.gov/fdsys/pkg/PLAW-108publ173/pdf/PLAW-108publ173. pdf. Accessed November 3, 2015.

10. Isetts BJ, Schondelmeyer SW, Artz MB, et al. Clinical and economic outcomes of medication therapy management services: the Minnesota experience. J Am Pharm Assoc (2003). 2008;48(2):203-11.

11. Bunting BA, Cranor CW. The Asheville project: long-term clinical, humanistic, and economic outcomes of a community-based medication therapy management program for asthma. J Am Pharm Assoc (2003). 2006;46(2):133-47

12. Bunting BA, Smith BH, Sutherland SE. The Asheville project: clinical and economic outcomes of a community-based long-term medication therapy management program for hypertension and dyslipidemia. J Am Pharm Assoc (2003). 2008;48(1):23-31.

13. Chrischilles EA, Carter BL, Lund BC, et al. Evaluation of the Iowa Medicaid pharmaceutical case management program. J Am Pharm Assoc (2003). 2004:44(3):337-49.

14. Smith M, Giuliano MR, Starkowski MP. In Connecticut: improving patient medication management in primary care. Health Aff (Millwood). 2011;30(4):646-54. Available at: http://content.healthaffairs.org/content/30/4/646.long. Accessed November 3, 2015.

15. Hirsch JD, Gonzales M, Rosenquist A, Miller TA, Gilmer TP, Best BM Antiretroviral therapy adherence, medication use, and health care costs during 3 years of a community pharmacy medication therapy management program for Medi-Cal beneficiaries with HIV/AIDS. J Manag Care Pharm. 2011;17(3):213-23. Available at: http://www.amcp.org/data/jmcp/213-223.pdf.

16. Zillich AJ, Jaynes HA, Snyder ME, et al. Evaluation of specialized medication packaging combined with medication therapy management: adherence, outcomes, and costs among Medicaid patients. Med Care. 2012:50(6):485-93

17. Pringle JL, Boyer A, Conklin MH, McCullough JW, Aldridge A. The Pennsylvania project: pharmacist intervention improved medication adherence and reduced health care costs. Health Aff (Millwood). 2014;33(8):1444-52.

18. Moczygemba LR, Barner JC, Lawson KA, et al. Impact of telephone medication therapy management on medication and health-related problems, medication adherence, and Medicare Part D drug costs: a 6-month follow up. Am J Geriatr Pharmacother. 2011;9(5):328-38.

19. Harris IM, Phillips B, Boyce E, et al. Clinical pharmacy should adopt a consistent process of direct patient care. Pharmacotherapy. 2014;34(8):e133-48 Available at: http://www.accp.com/docs/positions/whitepapers/pubprofreltnswp_final_web.pdf. Accessed November 3, 2015.

20. Patient-Centered Primary Care Collaborative. The patient-centered medical home: integrating comprehensive medication management to optimize patient outcomes. Resource guide, 2nd ed. 2012. Available at: https:// www.pcpcc.org/sites/default/files/media/medmanagement.pdf. Accessed November 3, 2015
21. Cipolle R, Strand L, Morley P. Pharmaceutical Care Practice: The PatientCentered Approach to Medication Management. 3rd ed. New York: McGraw-Hill Medical; 2012.

22. Oliveira DR, Brummel AR, Miller DB. Medication therapy management: 10 years of experience in a large integrated health care system. J Manag Care Pharm. 2010;16(3):185-96. Available at: http://www.amcp.org/data/ jmcp/185-195.pdf.

23. Peterson AM, Nau DP, Cramer JA, Benner J, Gwadry-Sridhar F, Nichol M A checklist for medication compliance and persistence studies using retrospective databases. Value Health. 2007;10(1):3-12. Available at: http://www. ispor.org/workpaper/research_practices/Peterson_Scientific_Report.pdf. Accessed November 3, 2015.

24. Nau D. Proportion of days covered (PDC) as a preferred method of measuring medication adherence. Pharmacy Quality Alliance. Available at: http://www.pqaalliance.org/images/uploads/files/PQA\%20PDC\%20vs\%20 \%20MPR.pdf. Accessed November 11, 2015.

25. Centers for Medicare \& Medicaid Services. Center for Medicare. Medicare health \& drug plan quality and performance ratings 2013 Part C $\&$ Part D technical notes. Draft. September 6, 2012. Page 64. Available at: https://www.cms.gov/medicare/prescription-drug-coverage/prescriptiondrugcovgenin/downloads/2013-part-c-and-d-preview-2-technical-notesv090612-.pdf. Accessed November 11, 2015.

26. Fishman PA, Goodman MJ, Hornbrook MC, Meenan RT, Bachman DJ, O'Keeffe Rosetti MC. Risk adjustment using automated ambulatory pharmacy data: the RxRisk model. Med Care. 2003;41(1):84-99.

27. Schneeweiss S, Wang PS, Avorn J, Maclure M, Levin R, Glynn RJ. Consistency of performance ranking of comorbidity adjustment scores in Canadian and U.S. utilization data. J Gen Intern Med. 2004;19(5 Pt 1):444-50.

28. Karve S, Cleves MA, Helm M, Hudson TJ, West DS, Martin BC. Good and poor adherence: optimal cut-point for adherence measures using administrative claims data. Curr Med Res Opin. 2009;25(9):2303-10.

29. Touchette DR, Shapiro NL. Medication compliance, adherence, and persistence: current status of behavioral and educational interventions to improve outcomes. J Manag Care Pharm. 2008;14(6 Suppl S-d):S2-10. Available at: http://www.amcp.org/data/jmcp/Aug08\%20Suppl\%20D_S2-S10.pdf.

30. DiMatteo MR. Variations in patients' adherence to medical recommendations: a quantitative review of 50 years of research. Med Care 2004;42(3):200-09.

31. Nieuwlaat R, Wilczynski N, Navarro T, et al. Interventions for enhancing medication adherence. Cochrane Database Syst Rev. 2014;CD000011. Available at: http://onlinelibrary.wiley.com/doi/10.1002/14651858. CD000011.pub4/full. Accessed November 3, 2015.

32. Sokol MC, McGuigan KA, Verbrugge RR, Epstein RS. Impact of medication adherence on hospitalization risk and healthcare cost. Med Care. 2005;43(6):521-30.

33. Doucette WR, McDonough RP, Klepser D, McCarthy R. Comprehensive medication therapy management: identifying and resolving drug-related issues in a community pharmacy. Clin Ther. 2005;27(7):1104-11. Available at: http://ac.els-cdn.com/S0149291805001463/1-s2.0-S0149291805001463main.pdf?_tid=a32b2148-cc06-11e4-992a-00000aab0f6c\&acdnat=14265291 40_750ef97921d55111058241b543d2f816. Accessed November 3, 2015.

34. Pindolia VK, Stebelsky L, Romain TM, Luoma L, Nowak SN, Gillanders F. Mitigation of medication mishaps via medication therapy management. Ann Pharmacother. 2009;43(4):611-20.

35. Murray MD, Ritchey ME, Wu J, Tu W. Effect of a pharmacist on adverse drug events and medication errors in outpatients with cardiovascular disease. Arch Intern Med. 2009;169(8):757-63. Available at: http://archinte.jamanetwork.com/article.aspx?articleid=414917. Accessed November 3, 2015. 